\title{
Not by Forestry Alone - A Balancing Act
}

By reference to my diary, I find that it was July 4 that we reached Chippewyan, and I remember rising before four o'clock, so eager was I to catch the first glimpse of the lake. We had been for nearly a month following down a river through a wilderness, where the range of our vision was limited by the high banks on either side, and it was like entering a larger world and was really restful when we beheld $a$ great expanse of blue water extending off to the east as far as the eye could reach.

ELIHU STEWART

Down The MackenzIe And Up The YUKON IN 1906 (LONDON, 1913)

11 ith increasing frequency, natural resource conflicts are surfacing from Newfoundland and Labrador to Alberta and British Columbia. Why are professionals with highly specialized training who practise in the public interest, coming under increased scrutiny? Reflecting on historical periods when the profession of forestry and the public have raised their voices provides a torchlight that may assist in recognizing situations before the dangers reach critical mass. (Irland 2007)

\section{First Glimpse}

From 1899 to 1911, conservation movements in the United States and Canada awakened the public interest. Conservation entered the federal political domain after 1893 with the implementation of forest reserve surveys and the creation of Moose Mountain Reserve in southern Saskatchewan. Clifford Sifton served as the Minister of the Interior under Sir Wilfrid Laurier from 1896 to 1905 and focused on material progress, encouraging government to act as a leader for private enterprise, using the strong arm of the law if necessary to ensure the public interest was being served. Laurier's priority of increasing national prosperity included driving the settlement process through economic western development through the adoption of "efficient and enlightened resource policies” (Gillis and Roach 1986).
Elihu Stewart, one of the founding fathers of the Canadian Institute of Forestry, and Superintendent of the Forestry Branch of the Department of the Interior, would bridge the gap of conservation and propagation by improving forest practices through the implementation of firefighting strategies, planned tree planting and the establishment of forest reserves in 1897. In 1900, Stewart created the Canadian Forestry Association and pushed for scientific management of forests, eventually placing 14000 square kilometres of forest reserves under the management and protection of the Dominion Forest Reserve Acts of 1906 and 1911. One of Stewart's greatest strengths was his ambition to become a leader in Canadian forestry. His practical experience, administrative abilities and avid enthusiasm in discussing forestry issues with all Canadians would see him influence government policy, raising the importance of forestry across Canada. The record shows that Prime Minister Sir Wilfrid Laurier often consulted with Stewart on forestry issues. In 1905, Stewart declared that establishing forestry schools in Canada would greatly advance forestry education and in 1907 the University of Toronto established the first Canadian forestry course, soon followed by the University of New Brunswick in 1908. The successor of the Dominion Forestry Branch, the Canadian Forest Service, continued Stewart's enduring vision of hiring graduates of Canadian forestry schools (Natural Resources Canada 2010).

Stewart would continue to recognize the importance of resource planning and development and foreshadowed the importance of oil sands development in his journey up the Athabasca River in 1906: "During the next eight days spent reaching Fort McMurray, the weather was almost tropical... where we first meet the tar sands. These sands bear a good percentage of bitumen. They extend for about ninety miles along the Athabaska. This bitumen is, the geologists tell us, an inspissated petroleum, derived from the sub-jacent limestones, and reports state

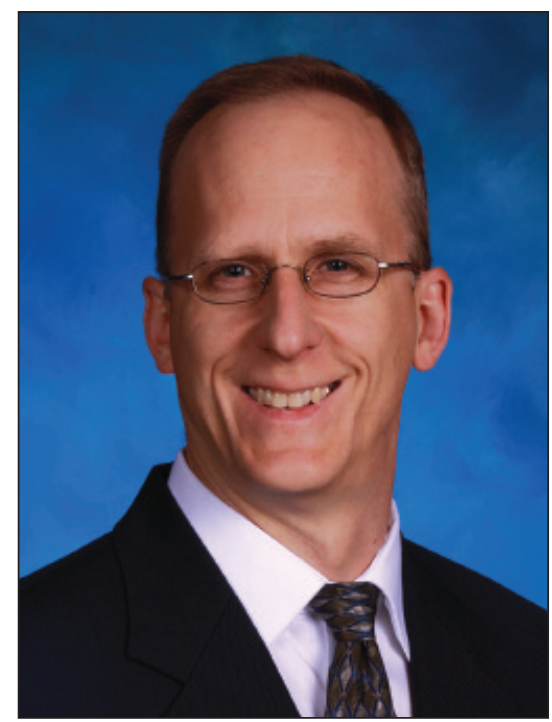

Mark Kube, R.P.F. CIF/IFC President/président

that indications of its presence extend over an area of 1000 square miles of country. It is more than probable that some day this may be one of the greatest oil producing districts in the world" (Stewart 1913).

\section{Range of Our Vision}

The year 1967 was of great significance to forestry in Canada. The Centennial year realized successful projects like Expo 67 with a national pride not seen since the end of the World Wars. The 2200 Canadian Institute of Forestry members were quietly preparing for the Centennial year with a joint meeting of the 16000 members of the Society of American Foresters in October of that year. The annual meeting theme "Not by Forestry Alone" would "examine how foresters and forestry are working within broadening associations of expertise and knowledge while, more and more, public and political forces and social and economic trends are exerting strong influences on forestry in North America"(Fensom 1972). President Lyndon Johnson greeted both organizations by stating "I am happy to greet the Joint Meeting of the Canadian Institute of Forestry and the Society of 


\section{THE FOREST ON YOUR DESKTOP}

\section{NATIONAL ELECTRONIC LECTURE SERIES}

Canadian Institute of Forestry / Institut forestier du Canada

\section{Forests without Borders:}

\section{Sharing Skills, Knowledge and Tools for Sustainable Community}

\section{Development Beyond Borders}

Special Lecture Series - \#8

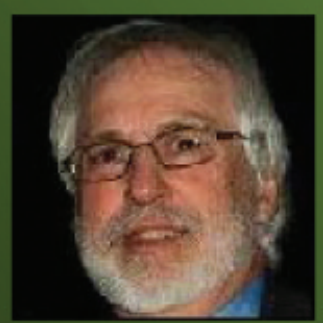

African Community Project

Garry Brooks

Founder, African Community Project

July $11^{\text {th }}, 2012$
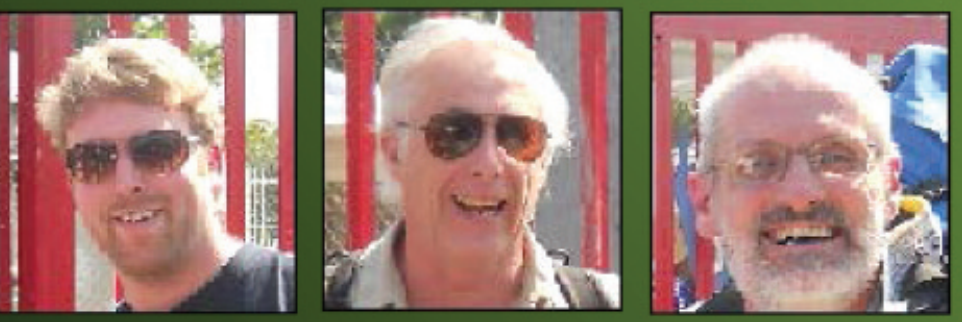

Haiti - From the Perspective of Three New Brunswick Foresters

\section{Chris Dickie}

Executive Director, INFOR Inc

Bruce Pendrel

Director of Science, Atlantic Forestry Centre (NRCan)

Ronald Smith

VarFor Ltd.

July $18^{\text {th }}, 2012$
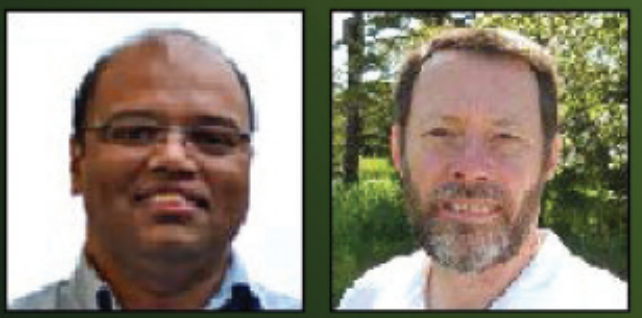

Forestry \& Environmental Education at School:

A Path Forward for Sustainable Community Development in Nepal

Dr. Bharat Pokharel

Postdoctoral Fellow, Nipissing University

Bill Clarke

Ecosystem Manager, Forest Ecology Centre, St. John's, NL

August 1 ${ }^{\text {st }}, 2012$

All electronic lectures are free. Your consideration of CIF/IFC membership would be appreciated.

FOR ADDITIONAL INFORMATION OR TO REGISTER, CONTACT;

Matt Meade

Email: mmeade@cif-ifc.org

Tel: (705) 744-1715 ext. 595

CIF

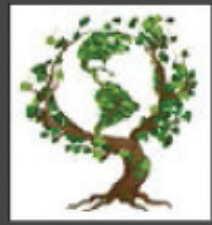

Fax: $(705) 744-1716$

Web: http://www.cif-ifc.org/site/electure

Web: http://www.fwb-fsf.org 
American Foresters. The citizens of our two great nations have long shared a deep respect and admiration for the work you are doing. No natural resource is more precious to us than our great forests-and none do more to preserve and increase those forests than the members of your profession. As a citizen, I enjoy the beauty and pleasures of our woodlands; as Chief Executive of the United States, I appreciate the work you are doing which provides millions of jobs, and ensures a constant supply of high quality wood, water, wildlife, scenery and recreation for the citizens of our countries. I salute you for your many accomplishments, and stand solidly with you for the intelligent management, use and conservation of our forests" (Fensom 1972).

\section{High Banks}

Des Crossley, upon reviewing his term of office as President of the CIF/IFC, wrote in the January 1967 edition of The Forestry Chronicle that it was unacceptable that the federal government had abandoned its shared cost forestry agreements. At a meeting with the Honourable Maurice Sauvé, the Minister of Forestry and Rural Development, Dean J.W.B. Sisam, Dr. L.Z. Rousseau, H.W. Beall and Crossley pressed for reinstating the cancelling of shared costs, the necessity for the early preparation of a National Forest Policy, the upgrading of forest management across Canada, and the desirability of federal leadership in areas of active cooperation with the provinces without infringing on provincial jurisdiction. Crossley would increase his criticism and state "the federal government's proclivity to hide behind the skirts of its constitutional responsibilities, to retreat into the area of research, its general reluctance to consider new ideas and solutions to meet large demand projects for wood, and its lack of a national forest policy." $\mathrm{He}$ also saw a strategic role for the CIF/IFC, "It seems high time that the Canadian Institute of Forestry, as a national body, should take a definite stand and, at this meeting, consider recommending the convocation, at the earliest possible date, of a high level conference of the provincial and federal governments to define jurisdictions once and for all in the field of forestry, and set the terms of reference for the formulation of an appropriate national policy." It should be noted, the Minister agreed to reconvene his Steering Committee to the 1966 National Forestry Conference and explore new approaches after meeting with the CIF/IFC Executive (Fensom 1972).

G.H. Bayly in Inner Bark, a 1967 insert in The Forestry Chronicle, cautioned the forestry profession on abdicating regional planning to other disciplines while still identifying the need for other specialists to be allowed in as valuable competition and providing stimulation to a profession badly in need of broadening perspectives and growth. Forest management activities "may be better done through a variety of disciplines than if one discipline has too exclusive a position" (Fensom 1972). E.S. Fellows at the 1967 annual meeting noted on a panel that "if we are to come close to satisfying the (public's) apparent needs, there must be some most imaginative planning supported by much more enlightened legislation than we have at present." He continued that professional foresters "should not attempt to define new policies on their own. They should certainly be amongst the leaders, but they should not presume that they are omniscient in a matter which has roots in so many different disciplines and which, in the final analysis, will be decided by public opinion-albeit a well-informed public opinion, we hope." (Fensom 1972).

\section{Entering a Larger World}

Vernon Knight in the April 1968 The Forestry Chronicle asked "What will tomorrow's forester be like?" He wrote "The influence of foresters in national resource policy matters is waning. Terms like 'good forestry' and 'conservation' are being re-defined by people who never heard of a forestry school. Woodlands are being merged into this realm called the 'total natural environment', and that's everybody's business. Yet, no other professional group in America is better qualified to speak with authority on natural resource management." The outstanding characteristics of the "tomorrow forester" included the ability to communicate and motivate; maintain high principles and integrity; display an enthusiastic desire to work and learn; hold an economic and business orientation; and be analytical, objective and well educated. Of particular relevance, is Gordon Weetman's June 1967 editorial that referenced Dr. P.H. Pimlott at a meeting of The Ontario Professional Foresters Association: "the profession assiduously avoids facing the most important issues of the day; foresters are often at the nub of political controversy, however fail to comprehend how political processes work; and fail to comprehend how public interest could work to their advantage" (Fensom 1972).

The case for Canadian foresters playing a role internationally was articulated by D.R. Redmond in August of 1968 in The Forestry Chronicle. He made the case for the CIF/IFC joining the proposed International Union of Foresters: "Canada has for sixty years had its own national society of foresters, and its members, as individuals, have played a very important part in international forestry, both through membership in the Commonwealth Forestry Association, and also as individuals who have gone on forestry missions to many countries in the world" (Fensom 1972).

The long standing principle of sustained yield has come under intense scrutiny for decades. Dr. David Haley provided a robust argument in a response to Leif Holt, who commented on a paper by J.C. Nautiyal and J.H.G. Smith in a paper prepared for the Ninth Commonwealth Forestry Conference in New Delhi: "In a dynamic world it is nonsense to think in only terms of an allowable cut based on vague notions of what is currently accessible and usable. Probably the fact which disturbs forest economics most about sustained yield is that it has ceased to be merely a method of timber yield regulation and has become an integral part of the dogma or 'conventional wisdom' of the forestry profession. The fact is that most of the benefits claimed for sustained yield are actually the result of continuous forest protection. That is, the issue is not usually the rate of harvest but whether the forest land is maintained in a productive state. We would like to reassure L. Holt that all forestry professors do not heap scorn on past forest teachings. We believe modern forestry education too often lacks that historical perspective and understanding that can only be obtained from knowledge of the accumulated experience and methodology 
of the past, such as is embodied in long established forest theory. We fully support Mr. Holt's criticism of the current attack on sustained yield-to us it smacks of erecting a strawman-and agree with his view on the significance of sustention and its practical application. We would only add that the sustained yield principle also has considerable values for government in facilitating the formulation of national forest policies and the development of sound continuing forest management practices that will satisfy all forest values. Even if we consider only timber values, the traditional basis for determining forest worth, we must recognize that the true source of forest wealth resides in the forest ecosystem" (Fensom 1972).

\section{As Far As The Eye Can Reach}

I can think of no better way to conclude this historical perspective than to quote Hamish Kimmins from his 1992 book: Balancing Act, Environmental Issues in Forestry. Because of the long time scale involved in forestry, it is important that society decide on a strategy for the use of its public land, and decide what it wants from public forests that are to be managed. The economic and management uncertainty that exists in the absence of a comprehensive and stable land-use strategy does not encourage sustainable forestry. And what might be sustainable forestry under one land-use strategy and management objective may be unsustainable under a different strategy and objective. Stable, long-term tenures with clearly defined and stable management objectives are as important to sustainable forestry as an ecological foundation is. Changes in objectives and land-use should be made only after careful consideration of the consequences of such changes for the quality of forest management. Such changes will inevitably be made from time to time, but must not be made in a manner that causes an unacceptable reduction in the sustainability of various values. A significant number of non-foresters are now equally concerned about sustainability, though the values they wish to sustain are often different from those that have been the traditional focus of foresters. This difference has been the cause of much of the present conflict between forestry and the environmental movement. It is time to resolve the conflict and recognize that both forestry and conservation have the same origin: sustainability. The energies and talents of both sides of the debate are urgently needed to design and implement systems that will sustain all the values we want from our forests."

\section{References}

Fensom, K.G. 1972. Expanding Forestry Horizons. A History of the Canadian Institute of Forestry/Institut Forestier du Canada 1908-1969. 547 p.

Gillis, P.R. and T.R. Roach. 1986. The American Influence on Conservation in Canada: 1899-1911. Journal of Forest History October: $160-174$.

Irland, L.C. 2007. Professional Ethics for Natural Resource and Environmental Managers: A Primer. Yale School of Forestry and Environmental Studies.

Kimmins, J.P. 1992. Balancing Act, Environmental Issues in Forestry. UBC Press.

Natural Resources Canada. 2010. Trailblazer - Elihu Stewart, 1844-1935 [online]. Available at http://www.nrcan.gc.ca/trailblazers/elihu-stewart/593.

Stewart, E. 1913. Down The Mackenzie and Up The Yukon In 1906. J. Lane, London.

\section{Pas seulement par la foresterie - une question d'équilibre}

«En consultant mon agenda, jai constaté que cétait le 4 juillet que nous avons atteint Chippewyan et je me souviens mêtre levé avant 4 heures, pressé d'avoir un premier aperçu du lac. Nous avions suivi pendant presqu'un mois une rivière à travers la nature sauvage, notre champ visuel étant limité par les rives abruptes sélevant de chaque côté et cétait comme pénétrer dans un monde plus vaste et plus relaxant lorsque nous nous sommes tenus devant une grande étendue d'eau bleue se prolongeant vers l'est aussi loin que nos yeux le permettaient. "

ELIHU STEWART

Down The MackenzIe And Up The YUKON IN 1906 (LONDON, 1913)

$\mathbf{D}_{\mathrm{p}}^{\mathrm{e}}$ plus en plus souvent, des conflits portant sur les ressources naturelles surgissent, de Terre-Neuve-Labrador jusqu'en Alberta et en Colombie-Britannique. Pourquoi est-ce que les professionnels ayant suivi une formation très spécialisée qui travaillent dans l'intérêt public, font de plus en plus lobjet de questionnement? Létude des périodes de l'histoire au cours desquelles les professionnels de la foresterie et le public ont élevé la voix apporte un éclairage qui pourrait être utile pour reconnaître certaines situations avant que le danger natteigne un niveau critique (Irland, 2007).

\section{Premier aperçu}

Entre 1899 et 1911, les mouvements de conservation aux États-Unis et au Canada ont soulevé l'intérêt du public. La conservation a fait son entrée dans le domaine politique fédéral après 1893 avec l'implantation des relevés des réserves forestières et la création de la Moose Mountain Reserve dans le sud de la Saskatchewan. Clifford Sifton était alors le ministre de l'Intérieur sous Sir Wilfrid Laurier de 1896 à 1905 et s'est concentré sur le progrès matériel, encourageant le gouvernement à devenir un chef de file de l'entreprise privée, utilisant, si nécessaire, la force des lois pour s'assurer que l'intérêt public était bien servi. La priorité de Laurier étant l'accroissement de la prospérité natio- nale, elle comprenait la mise en place d'un processus de colonisation au moyen du développement économique de l'Ouest suivant l'adoption de « politiques efficaces et judicieuses portant sur les ressources » (Gillies et Roach 1986).

Elihu Stewart, l'un des fondateurs de l'Institut forestier du Canada, et surintendant de la Direction fédérale des forêts du Département de l'Intérieur, va chercher à combler l'écart entre la conservation et le développement en améliorant les pratiques forestières par l'implantation de stratégies de lutte contre les feux de forêt, la plantation planifiée d'arbres et la création de réserves forestières en 1897. En 1900, Stewart crée l'Association forestière canadienne et met de l'avant un aménagement scientifique des forêts, plaçant 14000 kilomètres carrés de réserves forestières sous la gestion et la protection de la Loi fédérale sur les réserves forestières en 1906 et en 1911. L'une des grandes forces de Stewart était son ambition dêtre un chef de file de la foresterie au Canada. Son expérience 
pratique, ses habiletés de gestionnaire et son enthousiasme débordant pour discuter des enjeux forestiers avec tous les Canadiens feront en sorte qu'il aura une influence sur les politiques gouvernementales, accroissant l'importance de la foresterie partout au Canada. Les documents de l'époque indiquent que le Premier Ministre Sir Wilfrid Laurier consultait souvent Stewart relativement aux questions de foresterie. En 1905, Stewart a souligné que la création d'écoles de foresterie au Canada permettrait de faire progresser de façon importante la formation en foresterie et en 1907, l'Université de Toronto mettait en place le premier cours de foresterie au Canada, suivie peu après par l'Université du Nouveau-Brunswick en 1908. Le successeur de la Direction fédérale des forêts, le Service canadien des forêts, a maintenu la politique visionnaire de Stewart d'engager des diplômés des écoles de foresterie du Canada (Ressources naturelles Canada 2010).

Stewart allait poursuivre en reconnaissant l'importance de la planification et du développement des ressources et entrevit l'importance du développement des sables bitumineux lors de son voyage vers l'amont de la rivière Athabasca en 1906: "Au cours des huit jours requis pour rejoindre Fort McMurray, la température a été presque tropicale... alors que nous aperçûmes une première fois des sables bitumineux. Ces sables contiennent un fort pourcentage de bitume. Ils sétendent sur environ quatre vingt dix milles le long de l'Athabaska. Ce bitume est, selon ce que nous ont dit les géologues, une forme brute de pétrole, dérivée des couches de pierres calcaires et les rapports mentionnent que les indices de leur présence sétendent sur une superficie de plus de 1000 milles carrés. Il est plus que probable qu'un jour cette région sera l'un des plus importants districts de production de pétrole au monde. " (Stewart 1913).

\section{Notre champ visuel}

Lannée 1967 a été d'une grande importance pour la foresterie au Canada. Lannée du Centenaire a vu la réalisation de projets couronnés de succès comme l'Expo 67 qui a suscité une fierté atteignant un niveau jamais vu depuis la fin des Guerres mondiales. Les 2200 membres de l'Institut forestier du Canada se préparaient tranquillement à cette année du Centenaire avec un congrès conjoint avec les 16000 membres de la Society of American Foresters qui s'est tenu en octobre de cette année-là. Le thème du congrès « Pas seulement par la foresterie» allait " étudier comment les forestiers et la foresterie travaillent en faisant appel à de nouvelles expertises et de nouvelles connaissances, tandis que de plus en plus, le public et les forces politiques ainsi que les tendances sociales et économiques exercent une influence déterminante sur la foresterie en Amérique du Nord » (Fensom, 1972). Le Président Lyndon Johnson a souhaité la bienvenue aux deux organisations en déclarant « Je suis heureux d'inaugurer le congrès conjoint de l'Institut forestier du Canada et de la Society of American Foresters. Les citoyens de nos deux grandes nations expriment depuis longtemps un profond respect et une grande admiration pour le travail que vous accomplissez. Aucune autre ressource naturelle nous est plus précieuse que nos immenses forêts-et personne d'autre n'en fait autant pour conserver et faire croître ces forêts que les membres de votre profession. En tant que citoyen, japprécie la beauté et les plaisirs offerts par nos forêts; en tant que Président des États-Unis, j’apprécie le travail que vous accomplissez qui permet de maintenir des millions d'emplois et assure un approvisionnement constant en bois de grande qualité et la présence d'eau, d'animaux sauvages, de paysages forestiers et d'activités récréatives recherchés par les citoyens de nos deux pays. Je vous rends hommage pour les nombreuses réalisations dont vous êtes à lorigine et je soutiens sans réserve votre gestion, utilisation et conservation intelligentes de nos forêts " (Fensom, 1972).

\section{Des rives abruptes}

Des Crossley, au moment de faire un bilan de ses réalisations à la fin de son mandat à titre de président de l'IFC/CIF, a écrit dans le numéro de janvier 1967 du Forestry Chronicle, qu'il était inacceptable que le gouvernement fédéral ait annulé le versement de sa part des ententes forestières. Lors d'une rencontre avec l'Honorable Maurice Sauvé, le ministre de la Foresterie et du Développement rural, le doyen J.W.B. Sisam, le Dr L.Z. Rousseau ainsi que H.W. Beall et Crossley ont insisté pour que soit annulé l'abandon du partage des coûts, sur la nécessité de lélaboration d'une ébauche d'une Politique nationale des forêts, sur la mise à jour des pratiques d'aménagement forestier au Canada et sur le souhait de voir le fédéral exercer un leadership dans des domaines impliquant la coopération des provinces sans empiéter sur les juridictions provinciales. Crossley accentuera sa critique en insistant sur « la propension du gouvernement fédéral à se cacher derrières les jupons de ses responsabilités constitutionnelles, à se cantonner dans le domaine de la recherche, son hésitation générale à retenir de nouvelles idées et des solutions innovatrices pour répondre aux grands projets forestiers et sur l'absence d'une politique forestière nationale. » Il prévoyait également un rôle stratégique pour l'IFC/CIF, « il semble grand temps que l'Institut forestier du Canada, en tant quorganisation nationale, prenne définitivement une position et, au cours de cette rencontre, envisage de recommander la tenue, le plus tôt possible, d'une conférence de haut niveau réunissant les gouvernements provinciaux et le fédéral pour définir les juridictions des uns et de lautre une fois pour toute pour tout ce qui touche le domaine de la foresterie, et établisse les termes de référence pour la formulation d'une politique forestière nationale. » On doit noter que le ministre accepta de maintenir en place son comité de direction pour la tenue de la Conférence nationale sur les forêts de 1966 et d'explorer de nouvelles approches après sa rencontre avec le bureau de direction de l'IFC/CIF (Fensom, 1972).

G.H. Bayly dans Inner Bark, un encart inséré en 1967 dans le Forestry Chronicle, prévient les professionnels de la foresterie du risque d'abandonner la planification régionale au profit d'autres disciplines, mais, identifie encore la nécessité de permettre à d'autres spécialistes de s'impliquer générant ainsi une saine compétition et pouvant stimuler une profession cherchant désespérément à ouvrir ses perspectives et à poursuivre sa croissance. Les activités d'aménagement forestier «peuvent probablement être mieux réalisées par l'entremise de plusieurs disciplines que par une seule qui occupe une position exclusive » (Fensom, 1972). E.S. Fellows lors du congrès annuel de $1967 \mathrm{a}$ indiqué lors d'une discussion entre panélistes que "si nous voulons à peu de chose près répondre aux besoins apparents (du public), il faut faire place à une planification beaucoup plus innovatrice 
qui s'appuie sur une législation beaucoup plus d'avant-garde par rapport à ce que nous avons en ce moment. " Il a ajouté que les forestiers professionnels « ne devraient pas chercher à élaborer de nouvelles politiques de leur propre initiative. Ils devraient certainement faire partie des chefs de file, mais ils ne devraient pas présumer qu'ils savent tout d'un sujet qui prend ses sources dans tellement de disciplines différentes et qui, en fin de compte, sera dirigé par l'opinion public-du moins une opinion publique bien informée, souhaite-on le. »

\section{Pénétrer dans un monde plus vaste} Vernon Knight dans le Forestry Chronicle d'avril 1968 demandait « À quoi le forestier de l'avenir ressemblera-t-il? ». Il écrit que " l'influence des forestiers sur les questions de politiques nationales des ressources s'amenuise de plus en plus. Des termes comme "saine foresterie " et " conservation " sont redéfinis actuellement par des personnes qui nont jamais entendu parler d'école de foresterie. Les forêts productives sont incorporées dans un domaine dénommé "l'environnement naturel global ", et tout le monde a droit de regard. Cependant, aucun autre groupe professionnel en Amérique n'est mieux qualifié pour discuter en toute connaissance de la gestion des ressources naturelles. » Les caractéristiques marquantes $\mathrm{du}$ « forestier de l'avenir » incluent la capacité de communiquer et de motiver, le respect de principes fondamentaux et l'intégrité, la volonté affichée de travailler et d'apprendre, le maintien d'une orientation économique et d'un sens des affaires et dêtre analytique, objectif et bien formé. Fait à noter, léditorial de Gordon Weetman publié en juin 1967 qui faisait référence au Dr P.H. Pimlott lors du congrès de l'Association des forestiers professionnels de l'Ontario : «la profession évite par tous les moyens de faire face aux enjeux les plus importants de l'heure, les forestiers sont souvent au cour des controverses politiques, mais sont incapables de saisir comment les processus politiques se développent et de comprendre comment l'intérêt public pourrait jouer en leur faveur» (Fensom, 1972).

Le rôle des forestiers canadiens sur la scène internationale a été décrit par D.R. Redmond en août 1968 dans le Forestry Chronicle. Il a démontré l'importance pour l'IFC/CIF de joindre l'Union internationale des forestiers sur le point de voir le jour : «Le Canada compte depuis 60 ans sa propre organisation nationale de forestiers et ses membres, en tant qu'individus, ont joué un rôle très important en foresterie internationale, à la fois en tant que membres de la Commonwealth Forestry Association et en tant qu'individus qui ont participé à des missions forestières dans plusieurs pays » (Fensom, 1972).

Le principe de rendement soutenu établi depuis longtemps a été étudié de façon intense pendant des décennies. Le Dr David Haley a rédigé un texte édifiant en réponse à Leif Holt qui commentait l'article de J.C. Nautiyal et de J.H.H. Smith publié lors de la $9^{\mathrm{e}}$ Conférence forestière du Commonwealth tenue à New Delhi : "Dans un monde en mouvement, il est tout à fait inapproprié de penser seulement en termes de coupe admissible basée sur de vagues notions de ce qui actuellement accessible et utilisable. Probablement le fait qui perturbe le plus l'économie forestière au sujet du rendement soutenu est qu'il n'est plus simplement une méthode de régularisation du rendement en matière ligneuse et qu'il est devenu un élément intégral du dogme ou de la "sagesse établie » au sein de la profession de la foresterie. Le fait est que la majeure partie des bénéfices attribués au rendement soutenu sont au fond le résultat de la protection continue des forêts. Finalement, cette question nest pas axée sur le niveau de récolte mais plutôt si le taux de productivité du territoire forestier est conservé. Nous souhaiterions rassurer L. Holt que tous les professeurs de foresterie nont pas décrié les enseignements du passé. Nous considérons que l’enseignement actuel de la foresterie manque trop souvent de recul et de compréhension des faits historiques qui ne peuvent être obtenus que par la connaissance de l'expérience accumulée et de la méthodologie utilisée alors, telles quon les retrouve dans la théorie forestière établie depuis longtemps. Nous supportons entièrement les critiques de M. Holt relativement aux attaques en cours contre le rendement soutenu-ce qui nous apparaît être une gifle à un pantin-et sommes d'accord avec sa vision de la signification de la durabilité et de son application pratique. Nous ajouterions seulement que le principe de rendement soutenu est d'une grande valeur pour les autorités gouvernementales en leur facilitant la formulation de politiques forestières nationales et le développement de saines pratiques d’aménagement forestier soutenu qui répondront à toutes les valeurs forestières. Même si nous ne considérons que les valeurs reliées au bois, la base habituelle utilisée pour déterminer la valeur monétaire des forêts, nous devons reconnaître que la vraie source de valeur des forêts réside dans l'écosystème forestier (Fensom, 1972).

\section{Aussi loin que nos yeux le perme- ttent}

Je ne pense pas à une autre façon de conclure cette perspective historique qu'en citant Hamish Kimmins tel qu'il l'a écrit dans son livre en 1992 : Balancing Act, Environmental Issues in Forestry. "Compte tenu des longues périodes de temps à considérer en foresterie, il est important que la société décide de la stratégie d'utilisation du territoire public et qu’elle décide ce qu’elle désire faire des forêts publiques sous aménagement. Les incertitudes économiques et managériales qui existent en l'absence d'une stratégie globale et stable d'utilisation du territoire n'encouragent pas la foresterie durable. Et ce qui pourrait être de la foresterie durable en fonction d'une stratégie d'utilisation du territoire et d'un objectif d'aménagement pourrait être non durable selon une stratégie différente et un autre objectif. Les tenures stables et à long terme affichant des objectifs clairement définis et stables d'aménagement sont aussi essentielles à la foresterie durable que les bases écologiques peuvent lêtre. Les modifications des objectifs et de l'utilisation du territoire ne devraient être faites quaprès une étude détaillée des impacts de ces changements sur la qualité de l'aménagement forestier. De tels changements seront inévitables à loccasion, mais ils ne doivent pas être faits d'une manière qui entraîne une réduction inacceptable de la durabilité de certaines valeurs. Un nombre significatif de forestiers s'inquiètent également de la durabilité, compte tenu que les valeurs qu'ils veulent rendre durables sont souvent différentes de celles qui ont été au cœur de l'attention habituelle des forestiers. Cette différence est en grande partie responsable du conflit actuel entre la foresterie et le mouvement environnemental. Il est temps de résoudre ce 
conflit et de reconnaître que la foresterie et la conservation ont toutes deux la même origine : la durabilité. L'énergie et le talent des deux parties opposées de ce débat sont requis immédiatement pour concevoir et mettre en place des systèmes qui assureront la durabilité de toutes les valeurs que nous voulons retirer de nos forêts. "

\section{References}

Fensom, K.G. 1972. Expanding Forestry Horizons. A History of the Canadian Institute of Forestry/Institut Forestier du Canada 1908-1969. 547 p.

Gillis, P.R. and T.R. Roach. 1986. The American Influence on Conservation in Canada: 1899-1911. Journal of Forest History October: $160-174$.

Irland, L.C. 2007. Professional Ethics for Natural Resource and Environmental Man- agers: A Primer. Yale School of Forestry and Environmental Studies.

Kimmins, J.P. 1992. Balancing Act, Environmental Issues in Forestry. UBC Press.

Natural Resources Canada. 2010. Trail-

blazer - Elihu Stewart, 1844-1935 [online]. Available at http://www.nrcan.gc.ca/trailblazers/elihu-stewart/593.

Stewart, E. 1913. Down The Mackenzie and Up The Yukon In 1906. J. Lane, London.

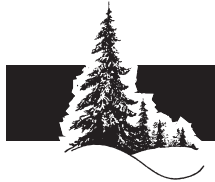

\section{One Hundred Years of Federal Forestry Presence in New Brunswick}

$T^{\text {he }}$ he Atlantic Forestry Centre is celebrating 100 years of forestry research in New Brunswick. The Canadian Forest Service (CFS) presence in New Brunswick had a humble beginning. In 1912, a two-room prefabricated wooden building was purchased at the cost of $\$ 200$ and put in place on the campus of the University of New Brunswick. This marked the beginning of the federal forestry presence in the province. The last century has seen many changes and improvements to the buildings that have served as laboratories and offices for the staff, culminating in the state-of-the-art facilities at the Hugh John Flemming Forestry Centre in Fredericton. The original role of federal forestry in the province was the protection of the forest from harmful insects, a role that is still prominent today. Over the years, research projects were expanded and now encompass many other vital areas of forest research.

John Douglas Tothill was the first federal forestry employee in $\mathrm{New}$ Brunswick. He was born in England in 1888 and came to Canada to study at the Ontario Agricultural College, where he specialized in entomology and botany. He later received a doctorate from Harvard University. After working for a short time with the US Bureau of Entomology Gypsy Moth Parasite laboratory, Tothill joined the Entomology Branch of the Dominion's Department of Agriculture (CFS antecedent) and set up a laboratory on the University of New Brunswick campus in Fredericton. Over the next 10 years, he directed intensive research on invasive pests, such as the brown-tail moth (Euproctis

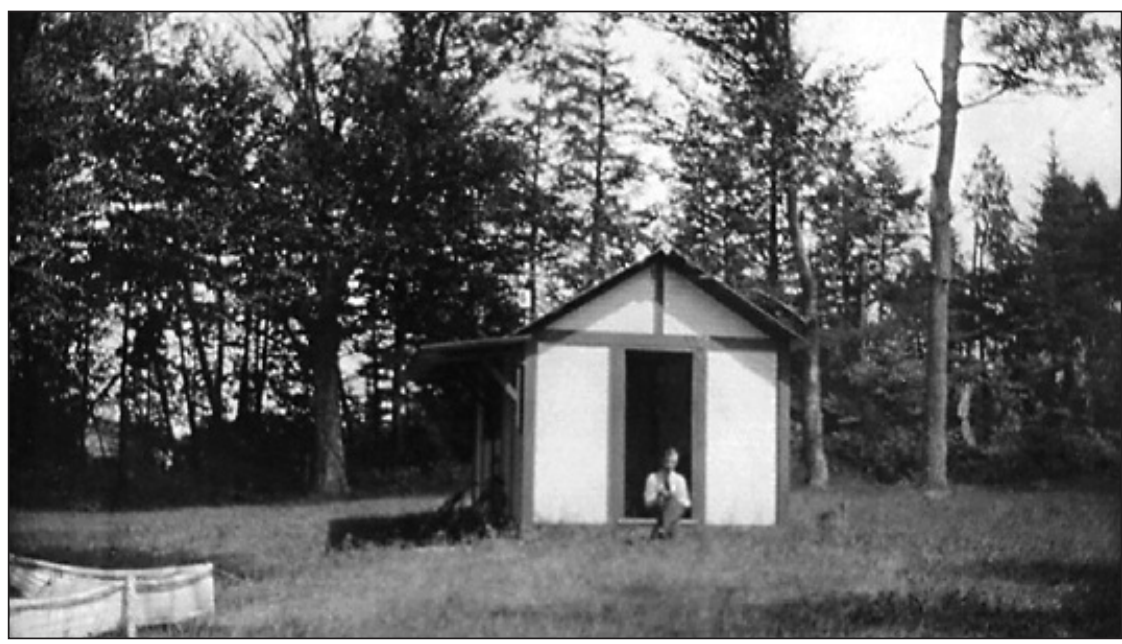

A humble beginning: this small two-room prefabricated wooden building on the University of New Brunswick campus was the first federal forestry laboratory in the province.

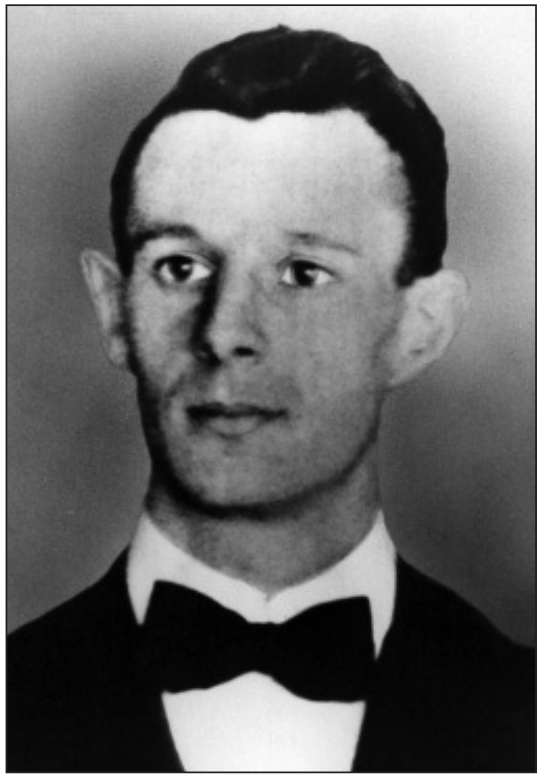

Field Officer John Douglas Tothill, New Brunswick's first federal forestry employee.

chrysorrhoae) and the gypsy moth (Lymantria dispar), and native insects such as the forest tent caterpillar (Malacosoma disstria), the fall webworm (Hyphantria cunea), and the spruce budworm (Choristoneura fumiferana). In 1923, Tothill transferred to the Forest Insect Division in Ottawa. In 1924, he was seconded to Fiji to fight the Levuana moth (Levuana iridescens) and became that country's Director of Agriculture. He later held similar posts in Uganda and Sudan. Although his career in Canada spanned but a dozen years, Dr. Tothill's work and legacy live on. $\mathrm{He}$ is credited with being the founder of 